FACTA UNIVERSITATIS

Series: Physical Education and Sport Vol. 16, Nº 1, 2018, pp. 189 - 199

https://doi.org/10.22190/FUPES161102017L

Research article

\title{
DIFFERENT LEVELS OF MOTOR ABILITIES IN BOYS AND GIRLS AGED 10 AND 9 \\ UDC 796.012.1 \\ 572.087
}

\section{Predrag Lazarević ${ }^{1}$, Srdjan Milosavljević ${ }^{1}$, Snežana Lazarević ${ }^{1}$, Vladan Marković ${ }^{2}$, Ana Savić ${ }^{3}$}

${ }^{1}$ College of Sports and Health, Belgrade, Serbia

${ }^{2}$ Faculty of Physical Culture and Sports Management, Singidunum University, Belgrade, Serbia

${ }^{3}$ Primary school 'Milutin i Draginja Torodović', Kragujevac, Serbia

\begin{abstract}
The aim of this research is to confirm differences in the anthropometric characteristics and motor abilities of schoolchildren aged 9 and 10 compared by sex and age. The sample comprised 341 schoolchildren, divided into two subgroups of third (172) and fourth (169) graders. The research is of a transversal character and includes the measurement of anthropometric characteristics and motor abilities by applying the Eurofit fitness testing battery. The results show a significant difference based on sex in terms of body mass $(t=2.148)$, and as for motor abilities, there is a difference in the Shuttle run test $(t=-3.709)$. A statistically significant difference considering the age of the tested population was observed in height $(t=-10.327)$ and body mass $(Z=-5,991)$, while in terms of motor abilities there was a statistically significant difference in the values of all the tests: Hand tapping $(t=4.735)$, the Standing long jump $(Z=-3,575)$, Shuttle run ( $t$ $=12,248)$, the Flexed arm hang $(Z=-2,167)$, Sit and reach $(Z=-2,406)$, Sit-ups in 30 seconds $(t=-9069)$. The research shows a higher statistically significant difference observed in body composition, but also in the motor area of the studied group in terms of age, and in relation to the statistically significant difference that was revealed by gender.
\end{abstract}

Key words: motor abilities, anthropometry, younger school age.

Received November 02, 2016 / Accepted March 20, 2018

Corresponding author: Snežana Lazarević

College of Sports and Health, St. Toše Jovanovića, Belgrade, Serbia

Phone: +3811175500 51•E-mail: snezanalazarevic@ vss.edu.rs 


\section{INTRODUCTION}

The technological evolution of modern man has a great influence on the younger population, especially in pre-adolescent and adolescent periods of development. The predominantly sedentary way of life is manifested in a lack of movement and has a negative impact on the development of motor skills, health, and the working capacity of children. During the period of growth and development of a child, the duration of required physical activity ranges from twelve to fifteen hours a week. This amount of physical exercise can only meet the basic needs of the body for movement. Through the teaching of physical education in elementary and high schools, following the prescribed PE curricula, three classes per week can satisfy ten to fifteen per cent of the basic needs of the body for movement (Krsmanović, 1996). Unlike previous interpretations, a recent definition of physical fitness reads a little more comprehensive and more complex: "The abilities of a man to by applying his locomotor apparatus, overcome any concrete movement and spatial requirements, naturally or artificially imposed, with the cooperation of his own speed, strength, endurance, integrity, agility, skills and accuracy, are concisely called physical abilities" (Ivanic, 2001: 52).

The prevalence of overweight and obesity in children has significantly expanded in many countries in Europe and the world (Wang, Monteiro \& Popkin, 2002; Ebbeling, Pawlak \& Ludwig, 2002; Guillaume \& Lissau, 2002). Inactivity and a sedentary way of life in children can generally be transmitted through childhood, even to old age (Haskell, et al., 2007). Due to its chronic complications, diabetes, which can be caused by excessive obesity, is considered to be the leading cause of cardiovascular disease, mortality, renal failure, blindness and amputations of the lower extremities (Permutt, Wasson \& Cox, 2005).

The morphological status of younger school age boys assessed by the BMI (body mass index) in the study conducted by Manic (2007) claims a significant impact of the morphological characteristics on the development of motor performance, and is an important predictor of the development of physical abilities of younger school age children. Also in a later study (Lazarević et al., 2011), the authors in their research came to similar conclusions. Namely, for subjects with weaker morphological characteristics a significantly poorer performance was recorded in 5 out of 6 tests conducted, two of which were designed to investigate the speed, and three of them coordination. Đorđević et al. (2016) have, however, come to the conclusion that there are significant differences in morphological and motor values of nine year-old-schoolgirls from Nis. The results of the motor tests were remarkably affected by the previously estimated BMI.

Attending elementary school from the ages of seven to eleven is of a vital importance for the development of a child. This period represents a sensitive stage for the formation of motor stereotypes but also for the significant improvement of motor abilities. Nićin (2000) states that the period from seven to eleven years of age is very sensitive and that this period creates better conditions for learning various movements and gestures, automation, motor experience, and that it is characterized by the occurrence of first physical deformities. Therefore, the period of early school age is considered to be a very sensitive, "critical" period in the development of the child. In order to develop motor abilities potential, it is necessary to be familiar with elements that can be influenced so as to develop movement actions. A large number of physiological and metabolic processes in the body take place under the influence of physical exercise and they can have a great influence on motor 
stereotypes formation. Major changes occur in bone and muscle, the cardio-vascular, endocrine and immune system (Mikalački, 2000; Mišigoj - Durakovic, 2006; Zivkovic et al., 2013; Lazarević et al., 2013). Bala and colleagues, in their study (2007) demonstrated a positive effect of physical exercise on the development of motor abilities, noting that the development of motor abilities works in different ways in children compared by sex and age. The impact of physical activity on the development of motor abilities of younger school age pupils presents a broad research field so that the objective of our research is also based on the confirmation of possible differences in anthropometric characteristics and motor abilities of schoolchildren aged 9 and 10 as compared to age and sex.

\section{METHODS}

\section{Participants}

This research is of a transversal character and was conducted on a sample of the third and fourth graders attending two elementary schools in the city of Kragujevac. The gym was during testing sufficiently spacious and brightly lit, with a minimum temperature of $22^{\circ} \mathrm{C}$.

The sample in this study comprised 341 participants, divided into two subsamples according to sex and age. The first group of participants consisted of the third grade schoolchildren ( 88 boys and 84 girls), and the second of ( 83 boys and 86 girls) fourth grade schoolchildren. The surveyed participants were involved in regular physical education curricula classes performed by the class teacher. All of the participants were healthy and able to attend physical education classes, without the use of supplementation in their diet and without any medical therapy, which would be an excluding factor in our study. The participants voluntarily agreed to participate in this study.

\section{Sample of variables and tests}

Body height was measured by an anthropometer according to Martin, with the participant standing in an upright position on firm level ground support with a strained back, close up heels, head where the Frankfurt plane is horizontal (Eremija, 1997). The result was read with an accuracy of $0,1 \mathrm{~cm}$. Assessment of body composition and weight measuring were done by a bioelectrical impedance method (Bioelectrical Impedance Analysis - BIA), (Kyle et al., 2004; Lim et al., 2009) in a physiological research laboratory of the Faculty of Medical Sciences in Kragujevac. After that, the participants performed warm-up and shaping exercises of moderate and medium intensity for a duration of 13 minutes - with the aim of physiological preparation of the body. The study was conducted by applying six standardized motor tests (Adam, Klissouras \& Ravassolo, 1988):

- Hand tapping (HT) - for assessing hand segmentary speed,

- The Standing long jump (SLJ) - for assessing explosive strength of the leg extensors,

- Shuttle run 10 × 5 m (SR 10 x 5 m) - for assessing speed,

- the Flexed arm hang (BAH) - to evaluate the upper body muscle isometric strength and the flexor of the elbow joint,

- Sit and reach (SAR) - for the evaluation of the lower back flexibility,

- Sit-ups in 30 seconds (SU-30 sec) - for the evaluation of repetitive strength of the abdominal muscles and the flexor in the hip joint. 
The obtained values of measured variables were statistically processed. Descriptive statistics was performed for all the variables while a Kolmogorov - Smirnov test was used to evaluate the normality of the tested variables. To determine the differences, a parametric independent $t$-test for small independent samples and the nonparametric Mann - Whitney test for parameters without normal distribution were applied. The difference of arithmetic means was calculated at the level of significance of $95 \%, p<0.05$. Statistical analysis was performed using the statistical package SPSS 20.0 for Windows.

\section{RESULTS}

Descriptive statistics and a comparison of the achieved results are presented in tables with values and statistical significances.

Table 1 Anthropometrical and morphological characteristics of the subjects third and fourth grade of primary school by gender

\begin{tabular}{lcccc}
\hline & $\mathrm{X} \pm$ SD & Min - Max & Med & Test \\
\hline & $\mathrm{BH}(\mathrm{cm})$ & & & Mann-Whitney \\
\hline Boys III (n=88) & $138 \pm 6,8$ & $123-156$ & 139 & $\mathrm{P}=0,661$ \\
Girls III (n=84) & $137,8 \pm 6$ & $125-154$ & 138 & $\mathrm{Z}=-0,438$ \\
Boys IV (n=83) & $149,5 \pm 7,2$ & $135-168$ & 148,5 & $\mathrm{P}=0,143$ \\
Girls IV (n=86) & $146,8 \pm 6,9$ & $133-161$ & 148 & $\mathrm{Z}=-1,466$ \\
\hline \multicolumn{5}{c}{$\mathrm{BW}(\mathrm{kg})$} \\
\hline Boys III (n=88) & $34,1 \pm 7,2$ & $23-54$ & 32,5 & Mann-Whitney \\
Girls III (n=84) & $32,4 \pm 5$ & $24-45$ & 32,0 & $\mathrm{P}=0,441$ \\
Boys IV (n=83) & $41,7 \pm 8,4$ & $28-73$ & 40 & $\mathrm{P}=0,771$ \\
Girls IV (n=86) & $38,6 \pm 8,4$ & $27-62$ & 36,5 & $\mathrm{Z}=-2,070$ \\
\hline & $\mathrm{BMI}$ & & $\mathrm{Mann}-$ Whitney \\
\hline Boys III (n=88) & $17,9 \pm 3$ & $13,1-27,6$ & 18 & $\mathrm{P}=0,243$ \\
Girls III (n=84) & $17 \pm 2$ & $13-22$ & 17,3 & $\mathrm{Z}=-1,166$ \\
Boys IV (n=83) & $18,5 \pm 2,9$ & $13,6-28,5$ & 17,8 & $\mathrm{P}=0,248$ \\
Girls IV (n=86) & $17,8 \pm 3$ & $13-28,3$ & 17,7 & $\mathrm{t}=1,162$ \\
\hline
\end{tabular}

$\mathrm{X}$ - means; SD - standard deviation; Min - minimum; Max - maximum; Med - median

$\mathrm{BH}$ - body heigh; BW - body weight; BMI - Body mass index; Statistical significance - * $\mathrm{P}<0,05 ; * * \mathrm{P}<0,01$

Table 2 Anthropometrical and morphological characteristics of the total population by sex (third and fourth grade)

\begin{tabular}{|c|c|c|c|c|}
\hline & $\mathrm{X} \pm \mathrm{SD}$ & Min - Max & Med & Test \\
\hline \multicolumn{3}{|c|}{$\mathrm{BH}(\mathrm{cm})$} & & Mann-Whitney \\
\hline Boys $(n=171)$ & $144,2 \pm 9,1$ & $123-168$ & 143 & $\mathrm{P}=0,127$ \\
\hline Girls $(n=170)$ & $142,3 \pm 7,9$ & $125-161$ & 141 & $Z=-1,527$ \\
\hline \multicolumn{3}{|c|}{ BW (kg) } & \multicolumn{2}{|r|}{ Independent T-test } \\
\hline Boys $(n=171)$ & $38,3 \pm 8,7$ & $23-73$ & 36,5 & $\mathrm{P}=0,033^{*}$ \\
\hline Girls $(n=170)$ & $35,6 \pm 7,6$ & $24-62$ & 34 & $t=2,148$ \\
\hline \multicolumn{3}{|c|}{ BMI } & \multicolumn{2}{|r|}{ Independent T-test } \\
\hline Boys $(n=171)$ & $18,2 \pm 2,9$ & $13,1-28,5$ & 17,8 & $P=0,061$ \\
\hline Girls $(n=170)$ & $17,4 \pm 2,6$ & $13-28,3$ & 17,3 & $t=1,886$ \\
\hline
\end{tabular}


Table 3 Anthropometrical and morphological characteristics of the total population by age

\begin{tabular}{|c|c|c|c|c|}
\hline & $\mathrm{X} \pm \mathrm{SD}$ & Min - Max & Med & Test \\
\hline & $\mathrm{BH}(\mathrm{cm})$ & & \multicolumn{2}{|c|}{ [ndependent T-test } \\
\hline III grade $(\mathrm{n}=172)$ & $137,8 \pm 6,4$ & $123-156$ & 138 & $\mathrm{P}=0,000 * *$ \\
\hline \multirow[t]{2}{*}{ IV grade $(n=169)$} & $148,3 \pm 7,1$ & $133-168$ & 148 & $\mathrm{t}=-10,327$ \\
\hline & $\mathrm{BW}(\mathrm{kg})$ & & & Mann-Whitney \\
\hline III grade $(n=172)$ & $33,2 \pm 6,2$ & $23-54$ & 32 & $\mathrm{P}=0,000^{* *}$ \\
\hline \multirow[t]{2}{*}{ IV grade $(n=169)$} & $40,4 \pm 8,5$ & $27-73$ & 39 & $Z=-5.991$ \\
\hline & BMI & & & Mann-Whitney \\
\hline III grade $(n=172)$ & $17,4 \pm 2,6$ & $13-28$ & 17,3 & $\mathrm{P}=0,130$ \\
\hline IV grade $(n=169)$ & $18,2 \pm 2,9$ & $13-28,5$ & 17,7 & $Z=-1.514$ \\
\hline
\end{tabular}

$\mathrm{X}$ - means; SD - standard deviation; Min - minimum; Max - maximum; Med - median; BH - body heigh; $\mathrm{BW}$ - body weight; BMI - Body mass index; Statistical significance $-* \mathrm{P}<0,05 ; * * \mathrm{P}<0,01$

Table 4 The values of motor abilities of the third grade schoolchildren by sex

\begin{tabular}{|c|c|c|c|c|}
\hline & $\mathrm{X} \pm \mathrm{SD}$ & Min - Max & Med & Test \\
\hline \multicolumn{4}{|c|}{ (HT- sec) } & Mann-Whitney \\
\hline Boys III ( $\mathrm{n}=88)$ & $15,7 \pm 2,3$ & $11,7-20,3$ & 15,3 & $\mathrm{P}=0,823$ \\
\hline Girls III $(n=84)$ & $16,1 \pm 3$ & $11,8-25,4$ & 15,7 & $Z=-0,223$ \\
\hline \multicolumn{4}{|c|}{$(\mathrm{SLJ}-\mathrm{cm})$} & Mann-Whitney \\
\hline Boys III $(\mathrm{n}=88)$ & $127,1 \pm 17,4$ & $80-155$ & 130 & $\mathrm{P}=0,430$ \\
\hline Girls III $(n=84)$ & $128,5 \pm 18$ & $80-155$ & 135 & $Z=-0,788$ \\
\hline \multicolumn{4}{|c|}{$(\mathrm{SR} 10 \times 5 \mathrm{~m}-\mathrm{sec})$} & Independent T-test \\
\hline Boys III $(n=88)$ & $26,4 \pm 2,9$ & $22,1-34,1$ & 25,7 & $\mathrm{P}=0,000 * *$ \\
\hline Girls III $(n=84)$ & $28,5 \pm 2,1$ & $23-35,2$ & 28 & $t=-3,709$ \\
\hline \multicolumn{4}{|c|}{$(\mathrm{BAH}-\mathrm{sec})$} & Mann-Whitney \\
\hline Boys III $(\mathrm{n}=88)$ & $10,6 \pm 7,6$ & $0-34$ & 10,5 & $\mathrm{P}=0,869$ \\
\hline Girls III $(n=84)$ & $9,8 \pm 4,4$ & $2-18$ & 10 & $Z=-0,164$ \\
\hline \multicolumn{4}{|c|}{$(\mathrm{SAR}-\mathrm{cm})$} & Mann-Whitney \\
\hline Boys III $(\mathrm{n}=88)$ & $4,9 \pm 3,1$ & $0-11$ & 4,5 & $\mathrm{P}=0,620$ \\
\hline Girls III $(n=84)$ & $5,5 \pm 3,1$ & $1-14$ & 5 & $Z=-0,495$ \\
\hline \multicolumn{4}{|c|}{$($ SU $30 \mathrm{sec})$} & Mann-Whitney \\
\hline Boys III $(\mathrm{n}=88)$ & $12,4 \pm 5,1$ & $3-23$ & 12 & $P=0,674$ \\
\hline Girls III $(n=84)$ & $12,7 \pm 4$ & $4-21$ & 12 & $Z=-0,420$ \\
\hline
\end{tabular}

$* * P<0,01 ; \mathrm{X}$ - means; SD - standard deviation; Min - minimum; Max - maximum; Med - median;

HT - Hand tapping; SLJ - Standing long jump; SR 10 x 5m - Shuttle run 10 x 5 m; BAH - Bent arm hang; SAR - Sit and reach; SU $30 \mathrm{sec}$ - Sit-ups in 30 seconds 
Table 5 The values of motor abilities of the fourth grade schoolchildren by sex

\begin{tabular}{|c|c|c|c|c|}
\hline & $\mathrm{X} \pm \mathrm{SD}$ & Min - Max & Med & Test \\
\hline \multicolumn{3}{|c|}{$(\mathrm{HT}-\mathrm{sec})$} & & Mann-Whitney \\
\hline Boys IV $(n=83)$ & $14,1 \pm 2,5$ & $10,1-21,3$ & 13,9 & $\mathrm{P}=0,559$ \\
\hline Girls IV $(n=86)$ & $14 \pm 2,5$ & $10,5-21$ & 13,7 & $Z=-0,526$ \\
\hline \multicolumn{4}{|c|}{$(\mathrm{SLJ}-\mathrm{cm})$} & Mann-Whitney \\
\hline Boys IV $(n=83)$ & $148,1 \pm 22,5$ & $105-190$ & 142,5 & $\mathrm{P}=0,001 * *$ \\
\hline Girls IV $(n=86)$ & $133,2 \pm 18,2$ & $95-165$ & 135 & $Z=-3,213$ \\
\hline \multicolumn{4}{|c|}{$(\mathrm{SR} 10 \times 5 \mathrm{~m}-\mathrm{sec})$} & Mann-Whitney \\
\hline Boys IV (n=83) & $22,4 \pm 1,8$ & $18,9-27,6$ & 22,4 & $\mathrm{P}=0,000 * *$ \\
\hline Girls IV $(n=86)$ & $23,9 \pm 1,6$ & $20,1-27$ & 24 & $Z=-4,197$ \\
\hline \multicolumn{4}{|c|}{$(\mathrm{BAH}-\mathrm{sec})$} & Independent T-test \\
\hline Boys IV $(n=83)$ & $9,5 \pm 7,7$ & $0-36$ & 9 & $P=0,197$ \\
\hline Girls IV (n=86) & $7,6 \pm 6,8$ & $0-37$ & 6 & $t=1,299$ \\
\hline \multicolumn{4}{|c|}{$(\mathrm{SAR}-\mathrm{cm})$} & Mann-Whitney \\
\hline Boys IV (n=83) & $3 \pm 5,4$ & $-10-12$ & 3 & $P=0,084$ \\
\hline Girls IV $(n=86)$ & $5 \pm 5,9$ & $-12-17$ & 6 & $Z=-1,730$ \\
\hline \multicolumn{4}{|c|}{ (SU $30 \mathrm{sec})$} & Mann-Whitney \\
\hline Boys IV $(n=83)$ & $18,9 \pm 4,1$ & $9-28$ & 19 & $P=0,179$ \\
\hline Girls IV (n=86) & $17,7 \pm 3,3$ & $4-23$ & 18 & $Z=-1,344$ \\
\hline
\end{tabular}

Table 6 The values of motor abilities of the total population by sex (third and fourth grade)

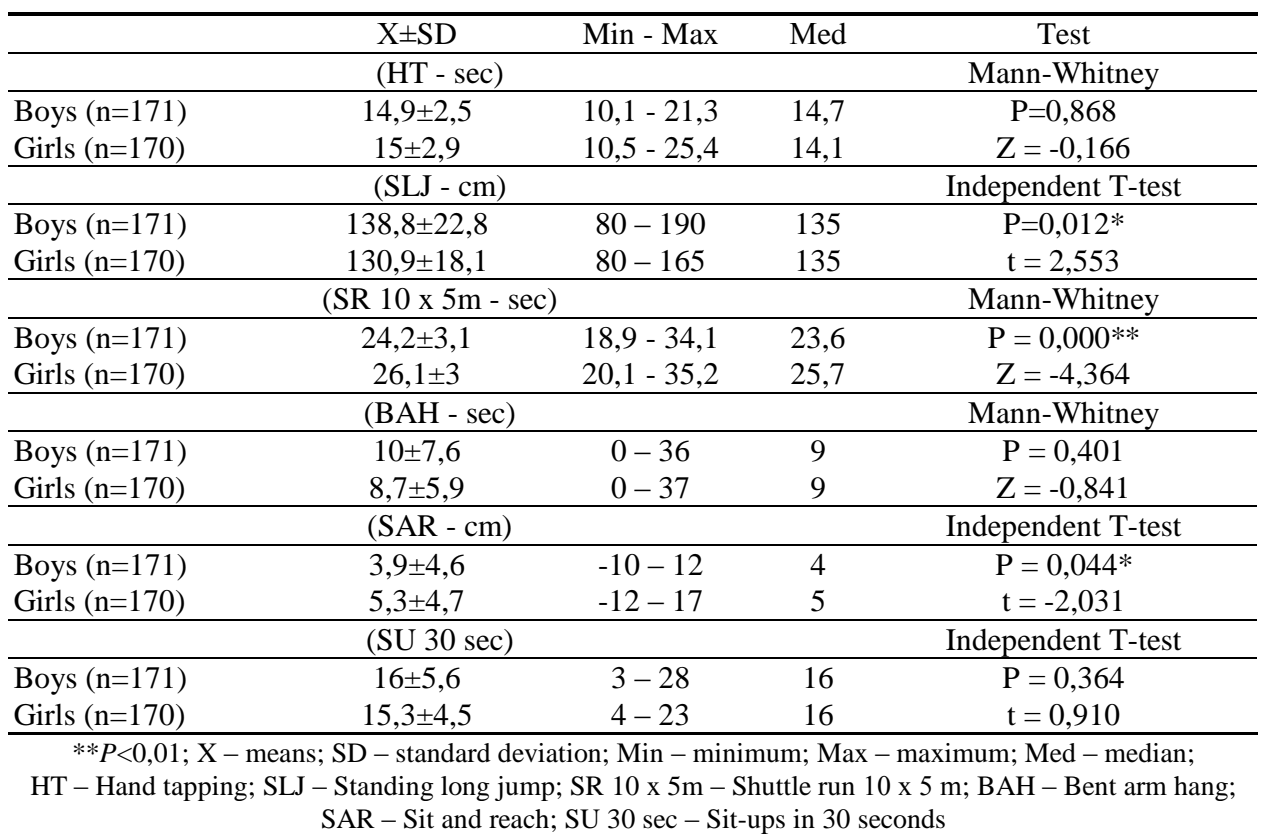


Table 7 The values of motor abilities of the total population by age (third and fourth grade)

\begin{tabular}{lcccc}
\hline & $\mathrm{X} \pm \mathrm{SD}$ & Min - Max & Med & Test \\
\hline & $(\mathrm{HT}-\mathrm{sec})$ & & & Independent T-test \\
\hline III grade $(\mathrm{n}=172)$ & $15,9 \pm 2,7$ & $11.7-25.4$ & 15,4 & $\mathrm{P}=0,000^{* *}$ \\
IV grade $(\mathrm{n}=169)$ & $14,1 \pm 2,47$ & $10,1-21,3$ & 13,8 & $\mathrm{t}=4.735$ \\
\hline & $(\mathrm{SLJ}-\mathrm{cm})$ & & & Mann-Whitney \\
\hline III grade $(\mathrm{n}=172)$ & $127,8 \pm 17,6$ & $80-155$ & 130 & $\mathrm{P}=0,000^{* *}$ \\
IV grade $(\mathrm{n}=169)$ & $141,4 \pm 22$ & $95-190$ & 140 & $\mathrm{Z}=-3.575$ \\
\hline \multicolumn{5}{c}{$(\mathrm{SR} 10 \times 5 \mathrm{~m}-\mathrm{sec})$} \\
\hline III grade $(\mathrm{n}=172)$ & $27,4 \pm 2,7$ & $22,1-35,2$ & 27,6 & $\mathrm{Independent} \mathrm{T-test}$ \\
IV grade $(\mathrm{n}=169)$ & $23,1 \pm 1,8$ & $18,9-27,6$ & 23 & $\mathrm{t}=12,248$ \\
\hline \multicolumn{5}{c}{$(\mathrm{BAH}-\mathrm{sec})$} \\
III grade $(\mathrm{n}=172)$ & $10,2 \pm 6,2$ & $0-34$ & 10 & $\mathrm{Mann}-$ Whitney \\
IV grade $(\mathrm{n}=169)$ & $8,7 \pm 7,4$ & $0-37$ & 7 & $\mathrm{Z}=-2.167$ \\
\hline & $(\mathrm{SAR}-\mathrm{cm})$ & & & Mann-Whitney \\
\hline III grade $(\mathrm{n}=172)$ & $5,2 \pm 3,1$ & $-10-14$ & 5 & $\mathrm{P}=0,016^{*}$ \\
IV grade $(\mathrm{n}=169)$ & $3,9 \pm 5,7$ & $-12-17$ & 4 & $\mathrm{Z}=-2.406$ \\
\hline & $(\mathrm{SU} 30 \mathrm{sec})$ & & & Independent T-test \\
\hline III grade $(\mathrm{n}=172)$ & $12,6 \pm 4,6$ & $3-23$ & 12 & $\mathrm{P}=0,000^{* *}$ \\
IV grade $(\mathrm{n}=169)$ & $18,4 \pm 3,8$ & $4-28$ & 18 & $\mathrm{t}=-9.069$ \\
\hline
\end{tabular}

\section{DISCUSSION}

A large number of studies are related to the development of anthropometric characteristics and motor abilities, but the obtained results in some studies differ, for example, in relation to the environment in which the given research was conducted.

The obtained results presented in the tables clearly indicate that there is no statistically significant difference in boys and girls aged 9, whereas among the fourth grade participants, children 10 years of age, there is a statistically significant difference in body mass. Namely, the boys had significantly higher body mass when compared to the girls in the studied population. Based on the obtained results it can be clearly concluded that the difference related to body mass in the tenth year of life occurs under the influence of sex characteristics.

The test results of the researched population of the third and fourth graders by age show a statistically significant difference in body height and body mass, which is a product of the biological development of both sexes.

Consequently, comparing the research results of the studies investigating motor abilities and anthropometric characteristics that some authors have obtained (Krsmanovic \& Radosav, 2008) in schoolchildren of both sexes aged 9-11, with the results of our research, we conclude that as our study showed that statistically better results were achieved by male subjects in standing long jump, while the results of the test hand taping in both studies show that there is no significant difference between boys and girls of the tested ages, the statistically significant difference in the test SLJ can also be explained by differences in sexual characteristics, bearing in mind that the boys of that age showed higher levels of explosive knee extensor strength than the girls of the same age. On the other hand, a higher value, but not statistically significantly higher for the body height and body mass, in our study, were observed in the male participants, which coincides with the results of a study 
conducted in a transversal study comprising 1489 participants ( 736 girls and 753 boys) in the city of Nis, where the difference in the values of body height and body mass in boys were significantly higher than the values of the girls (Gligorijević, 2008).

In contrast to our study where the male participants achieved better results in body mass, but not statistically significant ones, the study of Krsmanovic and Radosav (2008) showed a statistically significant difference in body height in favor of girls of the same age.

By comparing the motor abilities value of the measured parameters for the third graders by gender, the results show that there is a statistically significant difference in the values of the test SR $10 \times 5 \mathrm{~m}$. Better results achieved by boys compared to the values achieved by the girls of the same age indicates a pronounced agility of boys of this age as compared to girls.

The project of monitoring physical abilities of primary school age children in the Republic of Serbia, implemented by the Institute of Sport in cooperation with the Ministry of Education and Ministry of Youth and Sports (2009) using the Eurofit test battery (Adam, Klissouras \& Ravassolo, 1988), shows that motor abilities of school boys and school girls aged nine and ten realized in the municipality of Cukarica (Belgrade) were inferior to the results of participants of both sexes in our study. The boys aged nine have achieved on average worse results by $0,3 \mathrm{~cm}$ in the standing long jump, while the girls achieved better results in the same test by $9,23 \mathrm{~cm}$. Participants of both sexes, aged ten, in our study achieved better results than the participants of both sexes in the municipality Cukarica (boys - 6,98 cm, girls - 9,28 cm).

Agility as a motor ability that was in this paper evaluated by SAR, has pointed to a better status of girls when it comes to this ability, which coincides with the majority of studies conducted on this or a similar population, especially in non-active athletes.

Of course, the level of motor abilities in general can be improved under the influence of a programmed, well-planned and properly carried out physical exercise in younger schoolchildren, regardless of gender (Pejčić, 2001; Milanovic, 2006). That a positive development is possible under the influence of a constant programmed physical activity was confirmed by previous studies that have demonstrated a positive impact of the physical exercise on coordination and agility (Tso \& Wong, 2002; Bilić, Blazevic \& Širić, 2007; Badrić, 2010).

Differences in motor abilities results both in this and in similar studies conducted in different localities can be explained by the influence of various factors, such as: the content of extra-curricular activities when it comes to physical exercise, the quality of the implementation of the physical education curriculum in certain areas, infrastructure-technical opportunities for qualitative physical education teaching, difference in the physical activity of children in urban and rural areas, and the like. For all these reasons it is important to take all the facts into account when making conclusions based on the results of this and other research studies, but also in the mutual comparison of the obtained results.

Perceiving the importance of a greater number of monitored components whose values are used to assess the health status of children as well as adolescents, the need to also constantly apply tests for the motor abilities assessment is emphasized. Obviously, the significance of the results is reflected in the benefits of the tested students, teachers who by conducting testing might perceive a possible need for creating an IEP (Individual Education Plan), parents, and society at large that could possibly develop a strategy for the prevention of health decline (Cvejić, Pejovic, \& Ostojic, 2013). 


\section{CONCLUSION}

The results of this research are consistent with previously conducted studies, but they also differ from some studies carried out in different geographical areas and under the influence of various sociological factors.

Recapitulating the obtained results, we can conclude that male school age participants aged nine and ten have shown more developed speed ability, agility, quickness and explosiveness of the lower extremities as compared to the female population of the same age, in which, on the basis of the obtained results, a higher level of the lower back flexibility was observed. However, there is a clear difference in the results in 5 out of 6 motor tests by age which can be justified by the biological age and the difference of one calendar year.

Research in the field of motor abilities enhances improvement in the practical teaching of physical education in the field of methodology appropriate for younger school age children through the possible introduction of mandatory monitoring of motor abilities and by applying valid tests for motor status assessment. The benefits of the results of our study can be viewed through the correction of physical education teaching, with the aim of increasing the quality of teaching, but also exerting greater influence on the development of motor abilities through possible working with separate male and female groups of younger school age children.

\section{REFERENCES}

Adam, C., Klissouras, V., \& Ravassolo, M. (1988). Eurofit. Handbook for the Eurofit test of physical fitness. Rome: Council of Europe. Committee for the Development of Sport.

Badrić, M. (2010). Utjecaj programiranog treninga na promjene u motoričkim sposobnostima učenika uključenih u rad školskog športskog društva [The impact of programmed training on the changes in motor abilities of pupils included in the work of a school sports society. In Croatian]. U: Zbornik radova 19. Ljetne škole kineziologa Republike Hrvatske (pp. 71-78). Poreč: Hrvatski kineziološki savez.

Bala, G., Stojanović, M., \& Stojanović, M. (2007). Merenje i definisanje motoričkih sposobnosti dece [Measurement and definition of the motor ability of children. In Serbian]. Novi Sad: Fakultet sporta $\mathrm{i}$ fizičkog vaspitanja.

Bilić, Ž., Blažević, S., Širić, V. (2007). Promjene motoričkih značajki dječaka uzrasta 7 godina u različitim procesima transformacija kao temelj za uključivanje u sportske škole [Changes in motor features of boys aged 7 in various processes of transformation as a basis for inclusion in sports schools. In Croatian]. Acta Kinesiologica, 1(1), 38-43.

Cvejić, D., Pejović, T., \& Ostojić, S. (2013). Assessment of physical fitness in children and adolescents. Facta universitatis - series: Physical Education and Sport, 11(2), 135-145.

Đorđević, M., Kostić, R., Pantelić, S., Uzunović, S., Milanović, Z., \& Mitrović, B. (2016). Morpho-metric status and level of nutrition in nine - year old girls. Facta Universitatis, Series: Physical Education and Sport, 1-11.

Ebbeling, C. B., Pawlak, D.B., \& Ludwig, D. S. (2002). Childhood obesity: public - health crisis, common sense cure. The Lancet, 360(9331), 473-482.

Eremija, M. (1997). Biologija razvoja čoveka sa osnovama sportske medicine-praktikum [Biology of human development with the fundamentals of sports medicine-practicum. In Serbian]. Beograd: Fakultet fizičke kulture.

Gligorijević, S. (2008). Antropometrijski parametric kao pokazatelji akceleracije rasta i prediktori gojaznosti pre adolescenata [Anthropometric parameters as indicators of growth acceleration and predictors of obesity in preadolescents. In Serbian]. Acta Medica Medianae, 47(2), 15-9.

Guillaume, M., \& Lissau, I. (2002). Epidemiology. In: W. Burniat, T. Cole, I. Lissau, \& Poskitt E. M. E. Child and adolescent obesity: Causes and consequences, prevention and management (pp. 28-49). Cambridge University Press: Cambridge. 
Haskell, W. L., Lee, I. M., Pate, R. R., Powell, K. E., Blair, S. N., Franklin, B. A., \& Bauman, A. (2007). Physical activity and public health: updated recommendation for adults from the American College of Sports Medicine and the American Heart Association. Circulation, 116(9), 1081.

Ivanic, S. (2001). Treningologija [Trainingology. In Serbian]. Beograd: Republički zavod za sport.

Krsmanović, T., \& Radosav, S. (2008). Razlike antropometrijskih karakteristika i motoričkih sposobnosti učenika uzrasta 9 - 11 godina [The differences in anthropometric characteristics and motor abilities of children aged 9 - 11. In Serbian]. Glasnik antropološkog društva Srbije, 45, 194-198.

Krsmanović, B. (1996). Čas fizičkog vežbanja [A physical education class. In Serbian]. Novi Sad: Fakultet fizičke kulture.

Kyle, U. G., Bosaeus, I., De Lorenzo, A. D., Deurenberg, P., Elia, M., Gómez, J. M., \& Scharfetter, H. (2004). Bioelectrical impedance analysis-part I: review of principles and methods. Clinical Nutrition, 23(5), 1226-1243.

Lazarević, P., Živković, V., Djurić, D., Čubrilo, D., Pantić, J., Vuletić, M., \& Jakovljević, V. (2013). Positıve effects of six months training program on inflammatory mediators in young soccer players. Journal of Advances in Biology, 3(3), 257-265.

Lazarević, P., Živković, V., Vuletić, M., Barudžić, N., \& Čubrilo, D. (2011). The relationship between sports engagement, body mass index and physical abilities in children. Serbian Journal of Experimental and Clinical Research, 12(1), 41-42.

Lim, J. S., Hwang, J. S., Lee, J. A., Kim, D. H., Park, K. D., Jeong, J. S., \& Cheon, G. J. (2009). Cross calibration of multifrequency bioelectrical impedance analysis with eight-point tactile electrodes and dual energy X - ray absorptiometry for assessment of body composition in healthy children aged $6-18$ years. Pediatrics International, 51(2), 263-268.

Manić, G. (2007). Multivarijantne razlike nekih biomotoričkih dimenzija učenika viših razreda osnovne škole u odnosu na količinu masnog tkiva [Multivariate differences of some biomotoric dimensions of upper primary school pupils in relation to the amount of body fat. In Serbian]. Acta Kinesiologica, 1(1), 44-48.

Mikalački, M. (2000). Teorija i metodika sportske rekreacije [Theory and methodology of sports recreation. In Serbian]. Novi Sad: Fakultet fizičke kulture.

Milanović, I. (2006). Efekti programirane nastave fizičkog vaspitanja u mlađem školskom uzrastu [The effects of programned PE classes in a younger age. In Serbian]. Magistarska teza, Beograd: Fakultet sporta $\mathrm{i}$ fizičkog vaspitanja.

Mišigoj-Duraković, M. (2006). Kinantropologija - biološki aspekti tjelesnog vježbanja [Kinanthropology the biological aspects of physical exercising. In Croatian]. Zagreb: Kineziološki fakultet.

Nićin, D. (2000). Antropomotorika [Antropomotorics. In Serbian]. Novi Sad: Fakultet fizičke kulture.

Pejčić, A. (2001). Razlike između dječaka i djevojčica od prvog do četvrtog razreda osnovne škole u morfološkim karakteristikama i motoričkim sposobnostima [The differences between boys and girls from the first to the fourth grades in morphological characteristics and motor abilities. In Croatian]. U: 10. Ljetne škole pedagoga fizičke kulture Republike Hrvatske. (pp. 137-139). Poreč: Hrvatski savez pedagoga fizičke kulture.

Permutt, M. A., Wasson, J. \& Cox, N. (2005). Genetic epidemiology of diabetes. Journal of Clinical Investigation, 115(6), 1431-39.

Tso, G., \& Wong, P. (2002). Fitness camp for obese children. Promotion \& Education, 9(1), 44-44.

Wang, Y., Monteiro, C., \& Popkin, B. M. (2002). Trends of obesity and underweight in older children and adolescents in the United States, Brazil, China, and Russia. The American Journal of Clinical Nutrition, 75(6), 971-977.

Zivkovic, V., Lazarevic, P., Djuric, D., Cubrilo, D., Macura, M., Vuletic. \& Jakovljevic, V. (2013). Alteration in basal redox state of young male soccer players after a six-month training programme. Acta Physiologica Hungarica, 100(1), 64-76. 


\section{RAZLIKE NIVOA MOTORIČKIH SPOSOBNOSTI DEČAKA I DEVOJČICA 9 I 10 GODINA}

Cil jistraživanja je potvrda razlika antropometrijskih karakteristika i motoričkih sposobnosti učenika 9 i 10 godina po polu i uzrastu. Uzorak je obuhvatio 341 učenika, podeljenih u dva subuzorka trećeg (172) $i$ četvrtog (169) razreda mlađeg školskog uzrasta. Itraživanje je transferzalnog karaktera $i$ obuhvata merenje antropometrijskih karakteristika $i$ motoričkih sposobnosti kroz Eurofit bateriju testova. Rezultati pokazuju po pol uznačajnu razliku vrednosti telesne mase $(t=2,148)$, a u motoričkim sposobnostima razlikuju se u testu Čunasto trčanje $10 \times 5 \mathrm{~m}$ $(t=-3,709)$. Statistički značajna razlika gledano uzrast testirane populacije je u telesnoj visini $(t=-$ 10,327) $i$ telesnoj masi $(Z=-5.991)$, dok se u motoričkim sposobnostima statistički značajno razlikuju u vrednostima svih testova: Taping rukom ( $t=4.735)$, Skok u dalj iz mesta $(Z=-3.575)$, Čunasto trčanje $10 \times 5 m$ ( $(t=12,248)$, Izdržaj u zgibu $(Z=-2.167)$, Pretklon sa dosezanjem u sedu $(Z=-2.406)$, ležanje-sed za $30 \mathrm{sec}(t=-9.069)$. Istraživanje pokazuje veću statistički značajniju razliku posmatrano telesnu kompoziciju, alii u motoričkom prostoru ispitivane grupe po uzrastu u odnosu na statistički značajnu razliku koja se pokazala po polu.

Ključne reči: motoričke sposobnosti, antropometrija, mlađi školski uzrast. 